\title{
Rancang Bangun Aplikasi Virtual Tour Lokasi Rekreasi dan Hiburan Keluarga di Pontianak
}

\author{
Dio $^{{ }^{* 1}}$, Novi Safriadi ${ }^{* 2}$, Anggi Srimurdianti Sukamto ${ }^{* 3}$ \\ *Program Studi Informatika Fakultas Teknik Universitas Tanjungpura \\ Jl. Prof. Dr. H. Hadari Nawawi, Kota Pontianak, 78115

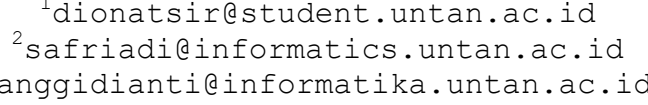

\begin{abstract}
Abstrak - Pontianak merupakan ibu kota Provinsi Kalimantan Barat dan dikenal sebagai kota khatulistiwa yang dilalui dua sungai besar yaitu Sungai Kapuas dan Sungai Landak. Selain itu, Pontianak ini juga mempunyai tempat rekreasi yang dapat menjadi objek wisata dan hiburan yang dapat dimanfaatkan sebagai tempat bersama keluarga ataupun teman, serta sebagai tempat untuk menarik wisatawan luar. Sebagai tempat rekreasi, maka dibutuhkan sebuah media untuk menyebarkan informasi kepada masyarakat dalam maupun luar Pontianak. Media informasi dapat menjadi saran untuk meningkatkan daya tarik pengunjung agar berkunjung ke suatu tempat rekreasi. Aplikasi virtual tour yang dikembangkan mampu memberikan informasi terkait kondisi tempat rekreasi yang ada. Aplikasi dibangun berbasis website sehingga dapat diakses oleh semua orang. Perancangan aplikasi ini menggunakan MDLC (Multimedia Development Life Cycle) yang terdiri dari 6 tahap, yaitu Concept, Design, Material Collecting, Assembly, Testing, dan Distribution. Aplikasi berjalan dengan baik dan bebas kesalahan berdasarkan pengujian black box, dan dinilai layak dengan hasil persentase $85,59 \%$ berdasarkan pengujian aspek usability, serta tampilan aplikasi dapat ditampilkan dengan baik melalui desktop maupun mobile browser berdasarkan pengujian portablity. Berdasarkan hasil pengujian, dapat disimpulkan bahwa aplikasi ini layak diimplementasikan.
\end{abstract}

Kata kunci-virtual tour, website, tempat rekreasi, MDLC.

\section{Pendahuluan}

Pontianak merupakan ibu kota Provinsi Kalimantan Barat yang dikenal sebagai kota khatulistiwa karena letaknya yang dilalui oleh garis khatulistiwa. Selain terkenal sebagai kota khatulistiwa, Pontianak mempunyai banyak lokasi rekreasi yang dapat dikunjungi oleh semua kalangan. Tempat rekreasi ini dapat menjadi objek wisata dan hiburan yang dapat diamanfaatkan sebagai tempat berkumbul bersama teman maupun keluarga.

Sebagai objek wisata, tempat rekreasi ini membutuhkan sebuah media informasi sebagai sarana meningkatkan daya tarik pengunjung yang akan berkunjung ke tempat rekreasi. Salah satu media informasi yang digunakan untuk penyebaran informasi adalah melalui website karena dapat diakses dimana saja oleh pengguna. Namun, informasi yang ditampilkan melalui website masih sebatas teks, gambar, ataupun video. Teknologi saat ini yang dapat dimanfaatkan dalam perkembangan media informasi adalah menggunakan virtual tour yang dibangun dalam media website.

Virtual tour adalah gabungan dari beberapa gambar panorama yang saling berhubungan dan ditampilkan dengan sudut pandang $360^{\circ} \mathrm{x} 180^{\circ}$. Virtual tour ini membuat pengguna seakan-akan berada langsung dalam lingkungan tersebut [1]. Selain virtual tour, aplikasi ini juga menampilkan deskripsi dan letak geologis dari tempat rekreasi serta pengunjung website dapat menambahkan tanggapan sebagai nilai tambah untuk tempat rekreasi tersebut. Melalui aplikasi ini, diharapkan pengguna mendapatkan informasi secara visual mengenai tempat rekreasi yang ada di Kota Pontianak.

\section{URAIAN PENELITIAN}

\section{A. Multimedia}

Multimedia merupakan kombinasi teks, gambar,seni grafis, suara, animasi, dan elemen-elemen video yang dimanipulasi secara digital. Meskipun definisi multimedia sangat sederhana, cara untuk menjalankannya sangat kompleks. Tidak cukup pemahaman tentang bagaimana setiap elemen multimedia dibuat dan bergerak. Namun juga diperlukan pengetahuan tentang bagaimana cara menggunakan piranti dan teknologi komputer multimedia untuk menggabungkan semua elemen bersama-sama.[11].

Aplikasi multimedia dapat digunakan diberbagai bidang, salah satunya dalam bidang publishing. Banyak informasi dapat dipublikasikan secara elektronik dan tersedia untuk pemakai. Biaya membuat dan mendistribusikan sebuah dokumen lebih rendah daripada menggunakan metode tradisional berupa cetakan. Dengan multimedia, dokumen dapat dikelola, diperbaharui dan dipelihara lebih mudah dan lebih murah. Dengan menggunakan multimedia untuk publik, banyak langkah lanjutan yang diperlukan dalam proses 
produksi dokumen berbasis kertas bias dikurangi. Dibandingkan materi cetak, publikasi multimedia dapat memberikan nilai tambah bagi pemakai, lebih dapat tersedia pada setiap waktu dan setiap tempat, interaktif, transparan dengan menggunakan hyperlink dan format multimedia. Keunggulan puncak dari Internet sebagai media publikasi online adalah dengan menyediakan infrastruktur pengiriman dokumen elektronik tanpa harus membuat infrastruktur WAN pendukung. [12].

\section{B. Foto Panorama}

Foto panorama adalah penggabungan beberapa foto yang tumpang tindih dengan tujuan untuk mendapatkan foto yang lebar dan mencakupi pemandangan yang luas. Foto panorama mampu mempresentasikan objek yang luas bahkan hingga $360^{\circ}$. Jenis foto panorama yang digunakan pada penelitian ini adalah panorama Equirectangular yang merupakan proyeksi bidang panorama yang dapat dilihat dengan sudut pandang $360^{\circ} \times 180^{\circ}$ sehingga seluruh arah dapat dimasukkan ke dalam foto [2].

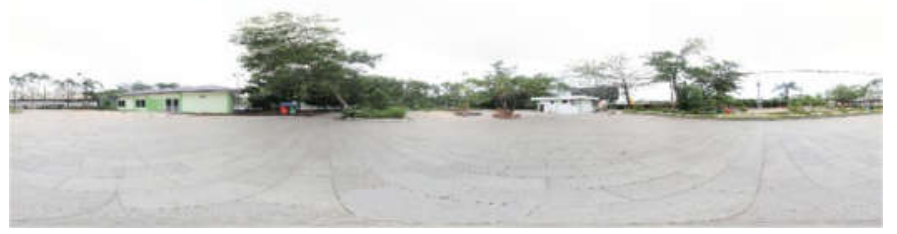

Gambar 1 Panorama Equirectangular

\section{Virtual Tour}

Virtual Tour adalah sebuah simulasi dari suatu lingkungan nyata, biasanya terdiri dari kumpulan foto-foto panorama, kumpulan gambar yang terhubung oleh hyperlink, ataupun video, atau virtual model dari lokasi yang sebenarnya, serta dapat menggabungkan unsur-unsur multimedia lainnya seperti efek suara, gambar, dan tulisan [3].

Istilah virtual tour atau panoramic tour sering digunakan untuk menggambarkan berbagai macam video dan media berbasis fotografi. Kata "panorama" mengindikasikan sebuah pandangan yang tidak terputus. Karena panorama bisa berupa sekumpulan foto memanjang ataupun hasil pengambilan video yang kameranya dapat berputar/bergeser. Tetapi istilah "panoramic tour" paling sering diasosiasikan dengan istilah virtual tour yang diciptakan dengan foto yang tidak bergerak. Virtual Tour ini dibuat dari sejumlah foto yang diambil dari sebuah titik pivot. Kamera dan lensa dirotasi berdasarkan apa yang disebut "nodal point" (suatu titik yang tepat berada pada bagian belakang lensadimana cahaya berkumpul).

Virtual tour digunakan untuk memudahkan user dalam melihat suatu lingkungan tanpa harus secara fisik melakukan perjalanan ke lokasi tersebut. Saat ini berbagai industri sudah menggunakan teknologi ini untuk membantu pemasaran jasa dan produk. Dalam penggunaannya, virtual tour diharuskan berbasis web sehingga dapat diakses dimana saja dan kapan saja. Selain itu, virtual tour yang kaya dan bermanfaat bukan hanya sekedar serangkaian gambar panorama saja. Sebuah pengalaman lebih baik dapat diperoleh dengan menampilkan beragam material seperti video, teks, dan gambar diam dalam sebuah konten web interaktif. Virtual Tour saat ini banyak digunakan dalam industri properti, pengenalan tempat wisata, pengenalan kampus, dan lain-lain.

\section{Easypano}

Easypano Holdings Inc. adalah salah satu pengembang dan pemasar perangkat lunak virtual tour terkemuka di dunia. Easypano telah menembus pasar global melalui distribusi internet yang maju dan kemitraan strategis dengan produsen dan pengembang. Easypano didirikan pada bulan November 2001, di Shanghai, China. Hingga Oktober 2013, Easypano telah memiliki lebih dari 30.000 pelanggan dari 180 negara. Solusi tur virtualnya telah diterima di seluruh dunia dan banyak digunakan di hampir setiap industry [4].

Dalam membuat virtual tour, Easypano menyediakan 2 perangkat lunak yang dapat digunakan dalam pembuatan aplikasi virtual tour, yaitu Panoweaver dan Tourweaver. Panoweaver adalah perangkat lunak yang digunakan untuk membuat gambar panorama. Sedangkan Tourweaver adalah perangkat lunak untuk membuat virtual tour yang berisikan kumpulan gambar panorama. Selain itu, Tourweaver dapat pula ditambahkan suara, video, lokasi dan berbagai fitur lainnya untuk membuat virtual tour.

\section{E. Multimedia Development Life Cycle (MDLC)}

Multimedia Development Life Cycle atau yang disingkat MDLC adalah metode perancangan aplikasi multimedia. Metodologi pengembangan multimedia terdiri dari 6 tahap,yaitu concept, design, material collecting, assembly, testing, dan distribution. Keenam tahap ini tidak harus berurutan dalam praktiknya, tahap-tahap tersebut dapat saling bertukat posisi. Meskipun begitu, tahap concept harus menjadi hal yang pertama kali dikerjakan [5].

1. Concept (Konsep)

Tahap concept (konsep) adalah tahap untuk menentukan tujuan dan siapa pengguna program (identifikasi audiens).

2. Design (Perancangan)

Design (perancangan) adalah tahap pembuatan spesifikasi mengenai arsitektur program, gaya, tampilan, dan kebutuhan material/bahan untuk program.

3. Material Collecting (Pengumpulan Bahan)

Material collecting adalah tahap pengumpulan bahan yang sesuai dengan kebutuhan yang dikerjakan.

4. Assembly (Pembuatan)

Tahap assembly adalah tahap pembuatan semua objek atau bahan multimedia.

5. Testing (Pengujian)

Tahap testing dilakukan setelah menyelesaikan tahap assembly dengan menjalankan aplikasi dan melihatnya apakah ada kesalahan atau tidak.

6. Distribution (Distribusi)

Pada tahap ini, aplikasi akan didistribusikan ke pengguna akhir. 


\section{Metodologi Penelitian}

Diagram alir (flowchart) penelitian yang digunakan untuk menjelaskan langkah-langkah perencanaan dalam melakukan penelitian. Berikut adalah diagram alir (flowchart) yang digunakan pada penelitian ini.

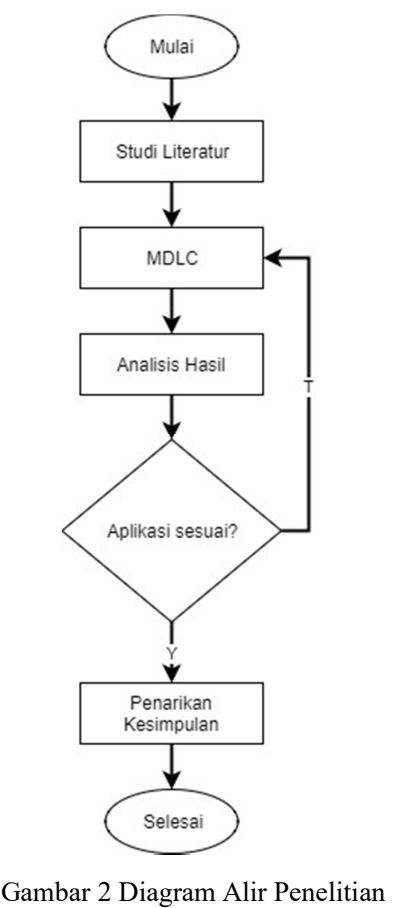

Metode pengembangan aplikasi yang digunakan dalam penelitian ini adalah Multimedia Development Life Cycle. MDLC digunakan sebagai perancangan aplikasi yang akan dibangun. MDLC terdiri dari 6 tahap, yaitu concept, design, material collecting, assembly, testing, dan distribution.

\section{A. Concept (Konsep)}

Ide dari pembuatan website ini adalah membuat suatu aplikasi yang dapat memberikan informasi tentang tempat rekreasi. Informasi yang diberikan seperti deskripsi dan lokasi geografis tentang tempat rekreasi yang ada di Kota Pontianak. Selain itu, website ini juga menampilkan tempat rekreasi tersebut dalam format virtual tour. Tempat rekreasi yang menjadi objek penelitian adalah beberapa taman yang ada di Kota Pontianak, yaitu Taman Akcaya, Taman Digulis, dan Taman Alun-Alun Kapuas. Tujuan dari website ini adalah sebagai media informasi mengenai tempat rekreasi dan hiburan keluarga di Pontianak yang dapat diakses melalui web browser dan ditampilkan secara virtual tour atau gambar panorama $360^{\circ} \times 180^{\circ}$

\section{B. Design (Perancangan)}

Perancangan aplikasi dengan melakukan desain terhadap aplikasi yang akan dibuat agar aplikasi berjalan sesuai kebutuhan pengguna.
1. Perancangan Arsitektur Sistem

Arsiterktur sistem adalah gambaran garis besar cara kerja sistem yang digambarkan melalui model-model yang saling berhubungan [13]. Arsitektur sistem menjelaskan komponen-komponen yang terdapat pada system [16]. Aplikasi dibangun berbasis website dan mempunyai dua golongan pengguna yaitu administrator dan pengunjung.

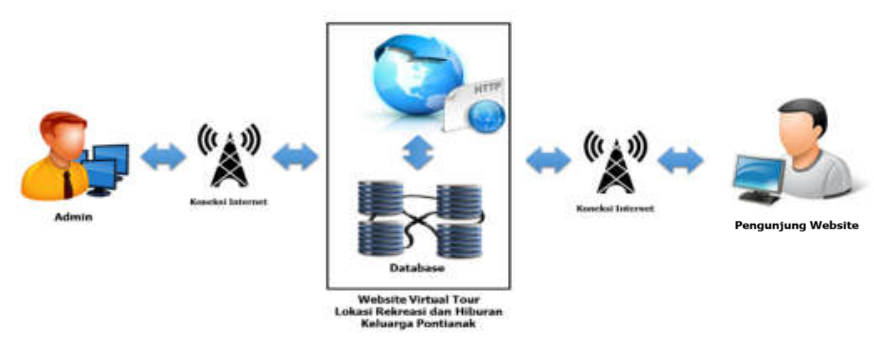

Gambar 3 Arsitektur Sitem

\section{Storyboard}

Storyboard yang akan dibuat merupakan perancangan dari tampilan virtual tour.

TABEL I

PERANCANGAN STORYBOARD

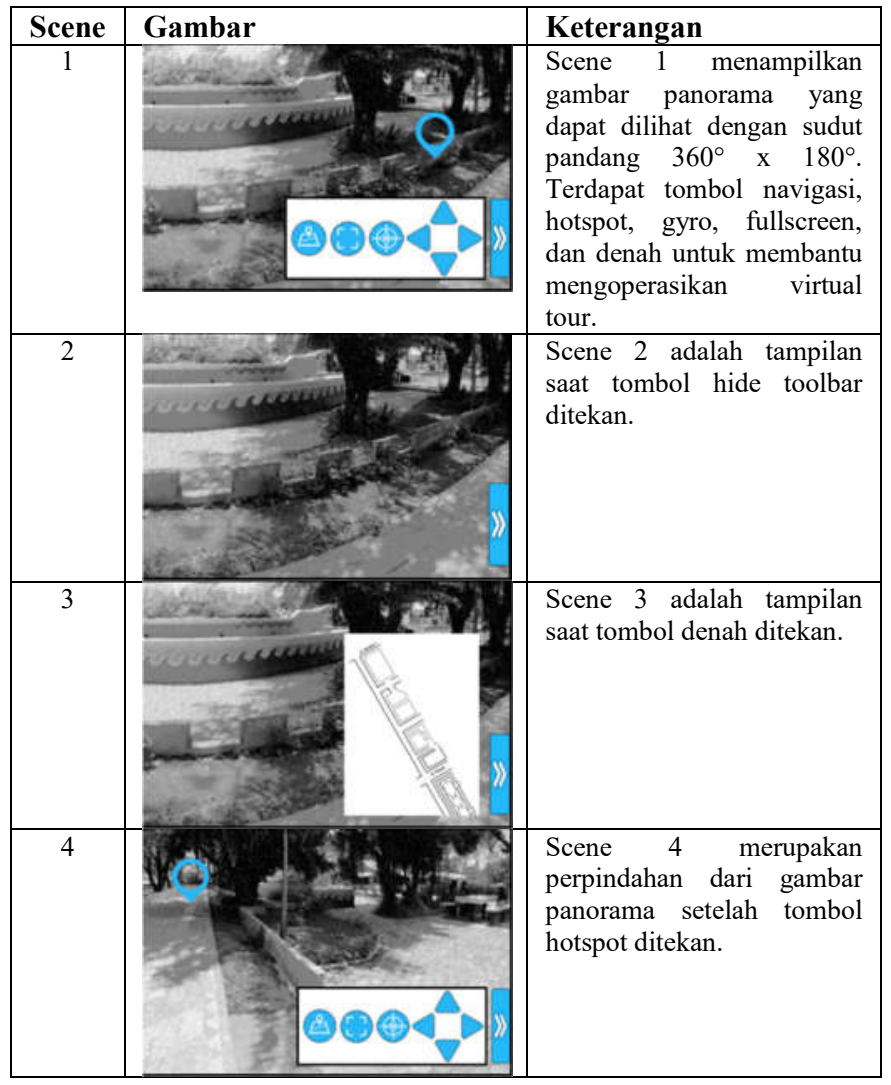


3. Perancangan Antarmuka

Perancangan antarmuka menggambarkan tentang tampilan dari aplikasi yang dibangun.

a. Struktur Antarmuka Halaman Depan

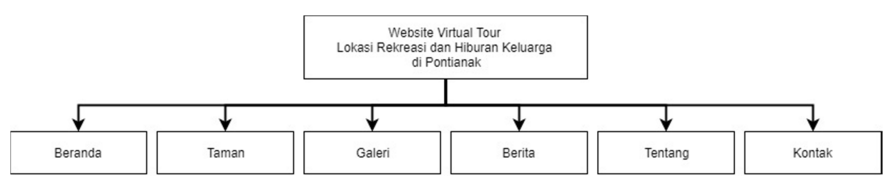

Gambar 4 Struktur Antarmuka Halaman Depan

b. Struktur Antarmuka Halaman Admin Panel

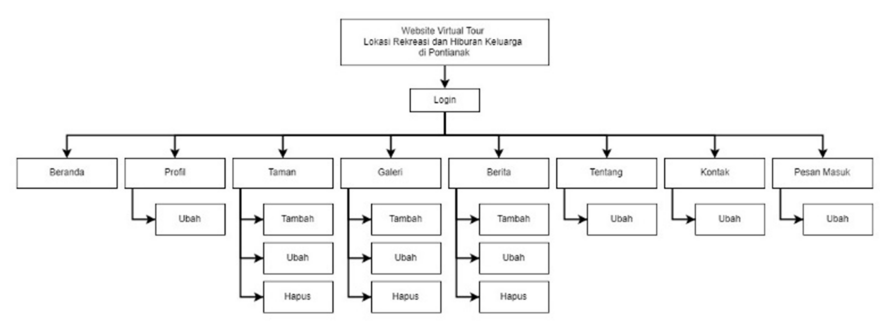

Gambar 5 Struktur Antarmuka Halaman Admin Panel

\section{Material Collecting (Pengumpulan Bahan)}

Bahan utama yang dibutuhkan dalam penelitian ini adalah foto panorama di tiap lokasi rekreasi yang dibagi menjadi beberapa titik untuk mewakili area lokasi penelitian. Bahan lain yang dibutuhkan adalah informasi umum terkait tempat rekreasi seperti alamat lokasi rekreasi.
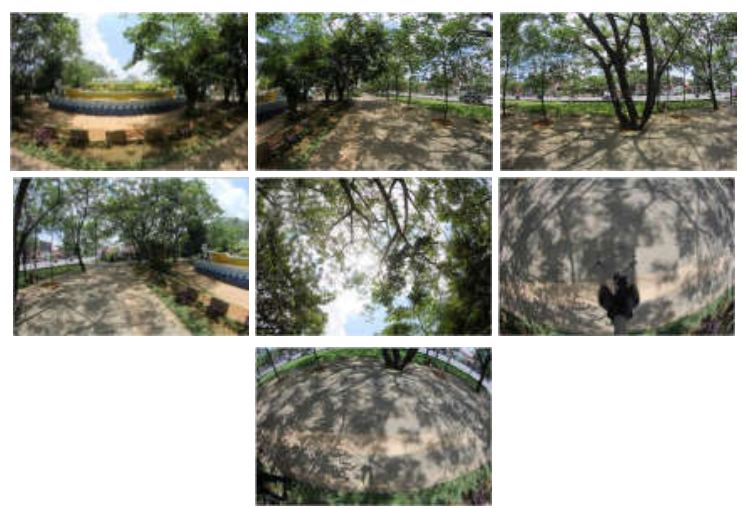

Gambar 6 Foto ke-7 Sisi Tiap Titik

Foto panorama diambil dengan kamera DSLR menggunakan lensa Fisheye, serta Tripod sebagai kaki kamera. Teknik pengambilan gambar dilakukan dengan 7 kali pengambilan gambar di tiap titik. Gambar yang diambil adalah 4 gambar horizontal, 2 gambar vertikal, dan 1 gambar lantai tambahan sebagai penunjang untuk menghilangkan tripod pada gambar.
Pengambilan gambar horizontal dilakukan dari sisi depan $\left(0^{\circ} / 306^{\circ}\right)$, kanan $\left(90^{\circ}\right)$, belakang $\left(180^{\circ}\right)$, dan kiri $\left(270^{\circ}\right)$. Sedangkan gambar vertikal dilakukan dari sisi atas $\left(0^{\circ}\right)$ dan bawah $\left(180^{\circ}\right)$. Gambar lantai tambahan dilakukan seperti mengambil gambar vertikal sisi bawah, namun pengambilan gambar tidak dilakukan menggunakan bantuan tripod.

\section{HASIL DAN ANALISIS}

\section{Assembly (Pembuatan)}

Pembuatan virtual tour dilakukan dengan menggabungkan gambar tiap titik pada lokasi rekreasi untuk dijadikan gambar panorama. Pembuatan gambar panorama menggunakan aplikasi Panoweaver. Setelah gambar panorama siap, gambargambar tersebut dihungjan menjadi virtual tour dengan aplikasi Tourweaver.

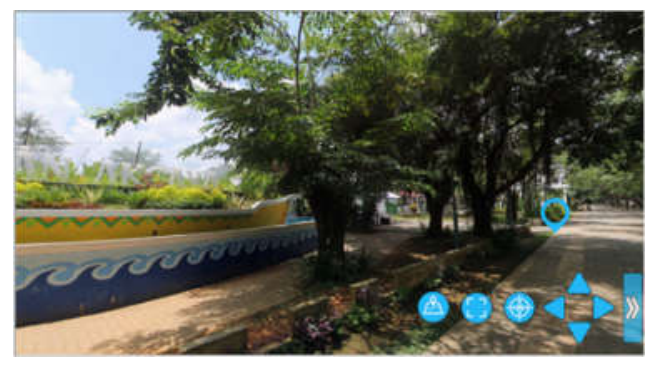

Gambar 7 Tampilan Virtual Tour

\section{E. Testing (Pengujian)}

Pengujian aplikasi menggunakan beberapa metode pengujian, yaitu black box, usability, dan portability.

1. Pengujian Black Box

Pengujian black box berfokus pada persyaratan fungsional perangkat lunak yang memungkinkan engineers untuk memperoleh set kondisi input yang sepenuhnya akan melaksanakan persyaratan fungsional untuk sebuah program [6]. Bentuk yang paling sederhana dari Black Box Testing (BBT) adalah dengan mulai menjalankan software dan melakukan pengamatan dengan harapan mudah untuk membedakan hasil yang diharapkan [15].

TABEL II

Hasil Pengujian Black Box PaDa TAMPILAN ViRTual TOUR

\begin{tabular}{|l|l|c|}
\hline Uji Skenario & Hasil yang diharapkan & Keterangan \\
\hline $\begin{array}{l}\text { Arahkan virtual tour } \\
\text { dengan tombol } \\
\text { navigasi arah }\end{array}$ & $\begin{array}{l}\text { Virtual tour dapat diarahkan ke } \\
\text { atas, kanan, bawah, dan kiri }\end{array}$ & Berhasil \\
\hline Pilih tombol denah & $\begin{array}{l}\text { Menampilkan popup window } \\
\text { denah lokasi }\end{array}$ & Berhasil \\
\hline Pilih tombol Gyro & $\begin{array}{l}\text { Virtual tour dapat diarahkan } \\
\text { sesuai orientasi dari perangkat } \\
\text { (hanya berfungsi pada perankat } \\
\text { yang memiliki sensor gyro) }\end{array}$ & Berhasil \\
\hline $\begin{array}{l}\text { Pilih tombol } \\
\text { Fullscreen }\end{array}$ & $\begin{array}{l}\text { Virtual tour ditampilkan dengan } \\
\text { layar penuh. }\end{array}$ & Berhasil \\
\hline $\begin{array}{l}\text { Pilih tombol } \\
\text { Show/Hide }\end{array}$ & $\begin{array}{l}\text { Menmpilkan/menyembunyikan } \\
\text { navigasi virtual tour }\end{array}$ & Berhasil \\
\hline
\end{tabular}


Pengujian black box dengan melakukan uji skenario, dinilai berhasil beroperasi dengan baik. Menu navigasi pada web berhasil mengarahkan ke halaman yang dituju. Tombol-tombol yang terdapat di dalam virtual tour berfungsi dengan baik. Fungsi-fungsi manajemen pada admin panel beroperasi dengan baik.

2. Pengujian Usability

Usability adalah atribut kualitas yang menilai betapa mudahnya user interface dari perangkat yang digunakan [7]. Pengujian aspek usability adalah bagian besar dari usaha untuk meningkatkan profitabilitas produk. Ada banyak aspek untuk melakukannya, yang pada akhirnya juga sangat menguntungkan pengguna: keputusan desain diinformasikan oleh data yang dikumpulkan dari perwakilan pengguna untuk mengekspos masalah desain sehingga mereka dapat diperbaiki , sehingga meminimalkan atau menghilangkan rasa frustrasi bagi pengguna [8]. Analisis pengujian aspek usability menggunakan skala likert. Skala Likert itu sendiri merupakan sebuah tabel untuk mencari skor terkecil dan terbesar dari sebuah test yang sudah ditanggapi oleh beberapa responden untuk mengetahui tingkat keberhasilan suatu aplikasi apakah bisa diterima atau tidak [14]. Skala likert digunakan untuk mengukur sikap, pendapat, dan persepsi seseorang atau sekelompok oarang tentang fenomena sosial [9].

TABEL III

HasilPenguJian Usability

\begin{tabular}{|c|c|c|c|c|c|c|}
\hline \multirow{2}{*}{ Aspek } & \multicolumn{7}{|c|}{ Hasil Pengujian } & Persentase \\
\cline { 2 - 7 } & STS & TS & CS & S & SS & Likert(\%) \\
\hline 1 & 0 & 1 & 4 & 42 & 33 & 86,75 \\
\hline 2 & 0 & 1 & 3 & 30 & 46 & 90,26 \\
\hline 3 & 0 & 0 & 9 & 37 & 34 & 86,25 \\
\hline 4 & 0 & 1 & 10 & 37 & 32 & 85 \\
\hline 5 & 0 & 1 & 10 & 44 & 25 & 83,25 \\
\hline 6 & 0 & 1 & 11 & 39 & 29 & 84 \\
\hline 7 & 0 & 0 & 11 & 48 & 21 & 82,5 \\
\hline 8 & 0 & 1 & 8 & 34 & 37 & 86,75 \\
\hline $\begin{array}{c}\text { Rerata } \\
\text { (\%) }\end{array}$ & 0 & 0,94 & 10,31 & 48,59 & 40,16 & 85,59 \\
\hline
\end{tabular}

Untuk menyimpulkan hasil akhir dari aplikasi, harus diketahui terlebih dahulu nilai interval total persentase dengan metode pencarian nilai interval pada persamaan. $I=100 /$ jumlah kriteria jawaban

$\mathrm{I}=100 / 5$

$\mathrm{I}=20$
TABEL IV

Kriteria Hasil PENGUJian USABILITY

\begin{tabular}{|c|l|}
\hline Interval Persentase & Kriteria \\
\hline $80 \%-100 \%$ & Sangat layak \\
\hline $60 \%-79,99 \%$ & Layak \\
\hline $40 \%-59,99 \%$ & Cukup layak \\
\hline $20 \%-39,99 \%$ & Tidak layak \\
\hline $0 \%-19,99 \%$ & Sangat tidak layak \\
\hline
\end{tabular}

Berdasarkan tabel di atas, dapat diketahui bahwa dari 80 responden nilai rata-rata persentase skala likert adalah $85,59 \%$ dan memasuki kriteria sangat layak digunakan.

3. Pengujian Portability

Pengujian ini bertujuan untuk menguji apakah aplikasi dapat berjalan di browser pada perangkat lain. Perangkat lunak dikatakan portable jika bisa dijalankan pada komputer lain, sehingga perangkat lunak yang sama bisa dijalankan pada banyak komputer yang berbeda [10].

TABEL V

HASIL PENGUJIAN PORTABILITY

\begin{tabular}{|c|c|c|}
\hline \# & Browser & Keterangan \\
\hline 1 & $\begin{array}{l}\text { Mozilla } \\
\text { (Desktop) }\end{array}$ & $\begin{array}{l}\text { Semua komponen dapat ditampilkan } \\
\text { dengan baik kecuali fitur gyro pada } \\
\text { virtual tour.. }\end{array}$ \\
\hline 2 & $\begin{array}{l}\text { Google } \\
\text { (Desktop) }\end{array}$ & $\begin{array}{l}\text { Semua komponen dapat ditampilkan } \\
\text { dengan baik kecuali fitur gyro pada } \\
\text { virtual tour }\end{array}$ \\
\hline 3 & $\begin{array}{l}\text { Firefox } \\
\text { (Mobile) }\end{array}$ & $\begin{array}{l}\text { Website ditampilkan secara } \\
\text { responsive, header video pada } \\
\text { halaman beranda tidak ditampilkan } \\
\text { dan diganti dengan gambar statis. }\end{array}$ \\
\hline 4 & Chrome (Mobile) & $\begin{array}{l}\text { Website ditampilkan secara } \\
\text { responsive, header video pada } \\
\text { halaman beranda tidak ditampilkan } \\
\text { dan diganti dengan gambar statis. }\end{array}$ \\
\hline
\end{tabular}

Pengujian portability menghasilkan bahwa aplikasi dapat dioperasikan pada desktop dan mobile browser. Aplikasi yang dioperasikan pada mobile browser tidak menampilkan video pada bagian header seperti tampilan pada desktop browser, hal ini dikarenakan video menggunakan resolusi yang lebih besar, sehingga tidak disarankan ditampilkan pada tampilan mobile browser. Selain itu, fitur gyro hanya dapat berfungsi pada mobile browser di smartphone $\$$ memiliki gyro sensor.

\section{F. Distribution (Distribusi)}

Aplikasi ini di-hosting di internet sehingga dapat diakses dimana saja dengan menggunakan desktop maupun mobile browser. Pendistribusian aplikasi ini dapat dilakukan melalui media sosial ataupun dengan menyisipkan link website saat menyebarkan angket pertanyaan pengujian usability. 


\section{KESIMPULAN}

Berdasarkan dari hasil analisis dan pengujian aplikasi virtual tour lokasi rekreasi dan hiburan keluarga di Pontianak, maka didapat kesimpulan seperti berikut:

1. Aplikasi virtual tour berbasis website berhasil dibangun dan dapat memberikan informasi kepada masyarakat tentang lokasi rekreasi dan hiburan keluarga yang ada di Kota Pontianak.

2. Hasil dari pengujian blackbox, aplikasi berhasil beroperasi dengan baik dan bebas dari kesalahan.

3. Hasil dari pengujian usability, bedasarkan jawaban dari responden menghasilkan nilai persentase dengan rata rata $85,59 \%$ dan masuk dalam kriteria sangat layak digunakan.

4. Hasil dari pengujian portability, aplikasi dapat beroperasi dengan baik melalui perangkat desktop maupun perangkat mobile.

\section{REFERENSI}

[1] H. W. Wulur, "Aplikasi Virtual tour Tempat Wisata Alam di Sulawesi Utara," Jurnal Teknik Informatika Universitas Sam Ratulangi, vol. 6, no. 1, 2015.

[2] Harianto, Rancang Bangun Aplikasi Virtual Tour Museum Provinsi Kalimantan Barat Untuk Edukasi Sejarah, Pontianak: Skripsi Program Studi Teknik Informatika, Universitas Tanjungpura, 2016.

[3] F. V. Handjojo, Perancangan dan Implementasi Aplikasi Content Management System dengan Format Virtual Online Tour, Pontianak: Skripsi Program Studi Teknik Informatika, Universitas Tanjungpura, 2013.

[4] Easypano Holding Inc, "Virtual Tour Software, Panorama Software, and Photo Stitching Software Developer: Easypano," [Online]. Available: http://www.easypano.com/companyinfo.html. [Diakses 30 Juli 2018].

[5] I. Binanto, Multimedia Digital - Dasar Teori dan Pengembangannya, Yogakarta: Penerbit Andi, 2010.

[6] R. S. Pressman, Pendekatan Praktisi Rekayasa Perangkat Lunak, Yogyakarta: Penerbit Andi, 2010.

[7] Z. Akamiyati, Pengembangan dan Analisis Kualitas Sistem Informasi Bimbingan Tugas Akhir Skripsi Online Untuk Mahasiswa Tingkat Akhir Pendidikan Teknik Elektronika FT UNY, Yogyakarta: Skripsi Program Studi Pendidikan Teknik Informatika, Univeristas Negeri Yogyakarta, 2016.

[8] J. Rubin dan D. Chisnell, Handbook of Usability Testing, Second Edition: How to Plan, Design, and Conduct Effective Tests, Indianapolis: Wiley Publishing, Inc, 2008.

[9] S. Vidiardi, Pengembangan Museum Virtual Interaktif Menggunakan Teknologi Desktop Virtual Reality Pada Museum Ranggawarsita, Semarang: Skripsi Program Studi Pendidikan Teknin Informatika dan Komputer, Universitas Negeri Semarang, 2015

[10] V. Salonen, "Automatic Portability Testing," 2012. [Online]. Available:

https://jyx.jyu.fi/bitstream/handle/123456789/40043/1/URN\%3A NBN\%3Afi\%3Ajyu-201210212735.pdf. [Diakses 30 Juli 2018].

[11] E. Shohifah, Aplikasi Virtual Taman Sari 3 Dimensi Menggunakan Unity, Yogyakarta: Skripsi Fakultas Teknologi Industri, Universitas Islam Indonesia, 2013.

[12] M. Suyanto, Multimedia Alat Untuk Meningkatkan Keunggulan Bersaing, Yogyakarta: Penerbit Andi, 2003.
[13] M. Redha, "Rancang Bangun Aplikasi Webgis Penyedia Jasa Properti Online Berbasis Virtual Online Tour," Jurnal Sistem dan Teknologi Informasi (JustIN), vol. 4, no. 3, pp. 356-360, 2016.

[14] Sugiyono, Memahami Penelitian Kualitatif, Bandung: Alfabeta, 2012.

[15] R. A. Sukamto dan M. Shalahuddin, Rekayasa Perangkat Lunak Terstruktur dan Berorientasi Objek, Bandung: Informatika, 2013.

[16] H. M. Raja, "Rancang Bangun Sistem Informasi Geografis Berbasis Web Fasilitas Pelayanan Kesehatan di Kota Pontianak," Jurnal Edukasi dan Penelitian Informatika (JEPIN), vol. 1, no. 2, pp. 64-71, 2015. 